\title{
KEMAMPUAN JUS JAMBU BIJI MERAH (PSIDIUM GUAJAVA L.) DIBANDING MULTIVITAMIN 500 MG DALAM MEMPERTAHANKAN ANTAL ERITROSIT PASCA SENAM AEROBIK HIGH IMPACT DI JURUSAN JAMU POLITEKNIK KEMENTERIAN KESEHATAN SURAKARTA
}

\author{
Sigit Tri Ambarwanto, M. Ali Nasikin \\ Poltekkes Kemenkes Surakarta Jurusan Jamu \\ Diterima : 7 Januari 2019, Disetujui : 5 Februari 2019
}

\begin{abstract}
Background: One of important missions from American Collage of Sports Medicine (ASCM) is to support physical activity in community. During high impact physical activity, oxygen consumption in whole bodies are increasing 20 times. This increasing of oxygen consumption may lead to increase of free radical production that can cause cell damage. One of free radicals, Hydrogen peroxide causes damage in red blood cell (erythrocyte) membrane, with the result decreasing of red blood cell life time, moreover inducing anemia. Substance that can inhibit damage cell caused by free radical called antioxidant. Antioxidants are plentiful in fruit and vegetables, especially colorfull fruits and vegetables. One of fruit that well known as antioxidant source is red guava (Psidium guajava). Red guava containing lycopen which is has high antioxidant activity. The aim of this study is to understand effect of red guava juice treatment to red blood cell serum level in respondent who given physical activity. Standard of comparison in this study is vitamin C (zegavit $500 \mathrm{mg}$ ). Method: this study used quasi experiment, independent variable is vitamin $C$ (zegavit $500 \mathrm{mg}$ ) and red guava juice treatment, dependent variable is red blood cell serum level. Results: The result of this study showed that there was no decreasing indication in red blood cells serum level of 3 groups. Conclusion: The conclusion in this study is there was no difference between red guava juice and vitamin C (zigavit $500 \mathrm{mg}$ ) treatment to avoid decreasing of red blood cells serum level after high impact physical activities.
\end{abstract}

Keywords: Vitamin C, Pantothenic Acid, Red Guava Fruit, High Impact Aerobic Exercise, Anti Erythrocytes.

\section{PENDAHULUAN}

Suatu misi penting American Collage of Sports Medicine (ASCM) adalah mendorong aktivitas fisik pada masyarakat. Ada berbagai macam olah raga yang di masukkan dalam latihan fisik, berdasarkan sumber tenaganya terdiri dari latihan aerobik dan anaerobik (Cooper, 2001).

Manfaat latihan aerobik bila dilakukan secara teratur dan menyenangkan, dengan intensitas latihan ringan sampai sedang akan meningkatkan kesehatan dan kebugaran tubuh. Latihan fisik dengan intensitas berat bisa menimbulkan terjadinya cidera. Selama latihan fisik maksimal konsumsi oksigen seluruh tubuh meningkat 20 kali lipat dan konsumsi oksigen pada serabut otot diperkirakan meningkat 100 kali lipat. Peningkatan konsumsi oksigen ini berakibat meningkatnya produksi radikal 
bebas yang dapat menyebabkan kerusakan sel. Untuk mencegah kerusakan akibat peningkatan radikal bebas ini dapat digunakan antioksidan. ( $\mathrm{Ji}$, et al., cit Hajar, 2004 ).

$$
\text { Radikal bebas dapat }
$$

mengakibatkan kerusakan pada membran eritosit sehingga umur sel darah merah yang mestinya dapat mencapai 120 hari menjadi berkurang dan menyebabkan anemia karena rusaknya sel darah merah akibat lisis. Kondisi anemia ini dapat mengakibatkan transport oksigen ke sel menjadi kurang sehingga akan mempengaruhi metabolisme sel yang dapat mengakibatkan sel sulit melakukan regenerasi (Guyton, 2002).

Oksidan/radikal bebas mempunyai peran penting dalam proses kerusakan sel, meningkatkan kapasitas antioksidan tubuh merupakan langkah tepat dalam menuju sehat sehingga perlu suplemen khusus untuk meningkatkan dan menjaga kondisi kesehatan tubuh. Berbagai macam suplemen antioksidan sudah banyak dikenal di dimasyarakat seperti vitamin C, vitamin E dan beta karoten. Pada latihan olah raga dengan intensitas tinggi dianjurkan diberikan tambahan bahan antioksidan (Cooper, 2001).

Suplemen alami belakangan ini mulai digemari masyarakat terutama yang berbentuk buah. Buah-buahan yang dikenal bagus sebagai sumber antioksidan antara lain adalah buah jambu biji merah. Penelitian mengatakan jambu biji merah mengandung suatu zat yang dinamakan likopen. Senyawa ini termasuk antioksidan berdaya kerja tinggi yaitu 2 kali lipat dibanding beta karoten dan sangat efektif melawan radikal bebas. Kandungan likopen pada jambu biji merah juga dapat mencegah kanker prostat, coronary heart disease (CHD) dan stroke (Vanket, et al., 2002)

Melihat kemampuan buah jambu biji merah yang demikian kuat dalam melawan radikal bebas maka perlu dilakukan penelitian untuk membandingkan kemampuan jus jambu biji merah dibanding zegavit $500 \mathrm{mg}$ (multivitamin) dalam mencegah penurunan kadar eritrosit pada mahasiswa yang latihan aerobik tipe high impact.

\section{METODE PENELITIAN}

Metode yang di gunakan dalam penelitian ini adalah quasi eksperiment dengan rancangan penelitian eksperimental pre dan post test yaitu dilakukan pengukuran sebelum dan sesudah perlakuan.

Subjek penelitian diambil dari populasi mahasiswa di asrama kampus III Politeknik Kesehatan dengan kriteria tertentu. Teknik sampling yang digunakan adalah porpusive sampling sebanyak 30 orang dan bersedia melakukan pemeriksaan laboratorium sebanyak 30 orang. Waktu penelitian yang dipergunakan selama 9 minggu. Analisa hasil penelitian dengan menggunakan uji paired $t$ - test.

\section{HASIL PENELITIAN}

Hasil dari penelitian ini meliputi pemeriksaan eritrosit pada 3 kelompok perlakuan, dimana kelompok pertama diberi treatment jus jambu, kelompok kedua diberi treatment zigavit, dan kelompok 3 diberi plasebo. Hasil pemeriksaan eritrosit dapat dilihat pada 


\section{Hasil Pemeriksaan Eritrosit pada} 3 Kelompok

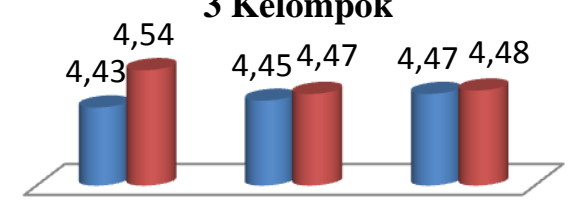

juss jambu zigavit kontrol

Gambar 1. Hasil pemeriksaan eritrosit pada ketiga kelompok

Berdasarkan bagan diatas terlihat

bahwa perubahan rata-rata eritrosit sebelum dan sesudah perlakuan meningkat paling tinggi pada kelompok dengan pemberian juss jambu. Sedangkan pada kelompok Zigavit dan control tidak mengalami penurunan eritrosit.

Tabel 1. Hasil uji statistic paired sample T-Test

\begin{tabular}{|c|c|c|c|c|c|c|}
\hline \multirow[b]{2}{*}{ Kelompok } & \multirow[b]{2}{*}{$\mathrm{N}$} & \multicolumn{2}{|c|}{ Mean } & \multicolumn{2}{|c|}{ Std. deviasi } & \multirow{2}{*}{$\begin{array}{l}-P \\
\text { value }\end{array}$} \\
\hline & & $\begin{array}{l}\text { Pre } \\
\text { test }\end{array}$ & $\begin{array}{l}\text { Post } \\
\text { test }\end{array}$ & $\begin{array}{l}\text { Pre } \\
\text { test }\end{array}$ & $\begin{array}{l}\text { Post } \\
\text { test }\end{array}$ & \\
\hline $\begin{array}{l}\text { Juss } \\
\text { Jambu }\end{array}$ & 10 & 4,42 & 4,54 & 0,347 & 0,345 & 0,065 \\
\hline Zigavit & 11 & 4,45 & 4,47 & 0,281 & 0,285 & 0,801 \\
\hline Kontrol & 10 & 4,47 & 4,48 & 0,328 & 3,29 & 0,746 \\
\hline
\end{tabular}

Dari tabel diatas terlihat bahwa

berdasarkan uji statistik paired sample ttest menunjukkan bahwa ketiga kelompok yang di berikan juss jambu, zigavit dan kelompok kontrol ketiganya memiliki nilai signifikan >0,05. Meskipun secara hasil nyata terlihat bahwa rata-rata eritrosit pada ketiga kelompok tidak mengalami penurunan. Namun secara statistik bahwa tidak ada pengaruh terhadap pemberian juss jambu maupun zigavit terhadap kenaikan jumlah eritrosit setelah senam high impact pada remaja putri.

Uji anova digunakan untuk mencari faktor yang paling efektif dalam mencegah penurunan kadar eritrosit. Berdasarkan hasil uji statistk terlihat bahwa signifikan $>0,05$ sehingga tidak terdapat perbedaan antara jus jambu dan zigavit/multivitamin dalam mencegah penurunan kadar eritrosit setelah senam high impact (hipotesis di tolak).

Tabel 2. Uji statistik yang paling berpengaruh (One Way Anova)

\begin{tabular}{llllll}
\hline Descriptive Statistics & & & & \\
& & & Std. & & Sig \\
& Perlakuan & Mean & Deviation & $\mathrm{N}$ & \\
\hline Pre_Test & Juss Jambu & 4.4260 & .34747 & 10 & .997 \\
& Zigavit & 4.4573 & .28139 & 11 & \\
& Kontrol & 4.4710 & .31831 & 10 & \\
& Total & 4.4516 & .30556 & 31 & \\
Post_Test & Juss Jambu & 4.5420 & .34595 & 10 & \\
& Zigavit & 4.4718 & .28597 & 11 & \\
& Kontrol & 4.4890 & .32909 & 10 & \\
& Total & 4.5000 & .31076 & 31 & \\
\hline
\end{tabular}

\section{PEMBAHASAN}

Penelitian ini dilakukan terhadap 30 remaja putri mahasiswa kampus 3 Poltekkes Surakarta yang dibagi menjadi 3 kelompok dengan masing-masing kelompok terdiri atas 10-11 mahasiswa. Selanjutnya tiap kelompok diberikan perlakuan yaitu Kelompok A diberikan juss Jambu, kelompok B diberikan multivitamin Zigavit dan kelompok $\mathrm{C}$ sebagai control. Masing-masing kelompok mendapatkan perlakuan selama 6 hari.

Hasil penelitian menunjukkan bahwa kenaikan rata-rata kadar trombosit pada table 2. paling tinggi adalah pada kelompok 1 yaitu kelompok perlakuan dengan juss jambu. Terdapat perbedaan rata-rata kadar eritrosit dari 4,42 menjadi 4,54. Namun secara statistic tidak terdapat perbedaan yang bermakna antara sebelum pemberian juss jambu dan setelah pemberian jus jambu yang di tunjukkan dengan nilai $p$ value 0,065 .

Hasil penelitian ditemukan jumlah sel darah merah berbeda secara nyata 
antara kelompok, namun peningkatan jumlah eritrosit yang jelas telihat pada kelompok A yang diberi perlakuan juss jambu, meskipun secara statistik menunjukkan tidak terdapat perbedaan antara pre dan post. Berdasarkan hasil uji anova menunjukkan bahwa antara ketiga kelompok tersebut dengan hasil statistik $\mathrm{p}$ value 0,997. Ini menunjukkan bahwa hipotesis ditolak. Sehingga tidak terdapat perbedaan secara bermakna antara ketiga kelompok dalam mencegah penurunan kadar eritrosit. Hal ini diduga karena kandungan yang terdapat pada jambu biji, khususnya kandungan Vitamin C tidak memiliki pengaruh terhadap jumlah kuantitas dari sel darah merah itu sendiri.

Proses pembentukan sel darah merah dipengaruhi oleh beberapa faktor, dan salah satunya dipengaruhi oleh faktorhormon eritropoietin, yaitu hormone yang dihasilkan oleh ginjal untuk memicu proses pembentukan sel darah merah dalam sumsum tulang (Ganong, 1997). Peningkatan produksi dan jumlah eritrosit akibat olahraga ini akan meningkan kadar hemoglobin total dalam darah, peningkatan konsentrasi hemoglobin ini akan meningkatkan uptake oksigen maksimal meskipun parameter hematologi lainnya tidak banyak berubah (Tipton, 2003).

Aktivitas fisik yang terus menerus tersebut akan menimbulkan keadaan hipoksia pada tubuh, pada level seluler keadaan hipoksia ini akan memicu faktor transkripsi HIF-1 (hypoxia induced factor1) yang berperan dalam adaptasi jaringan terhadap keadaan rendah oksigen, HIF-1 pada jaringan di ginjal dan hati akan memicu teranskripsi gen eritropoietin sehingga akan dihasilkan eritropoietin yang akan dilepas ke peredaran darah (Williams, 2007). Teori ini juga didukung oleh penelitian yang memaparkan individu yang hidup di dataran rendah dengan kondisi rendah oksigen pada dataran tinggi, kondisi hipoksia yang terus menerus ini didapati meningkatkan kadar hemoglobin secara signifikan (Calbet, 2002).

\section{KESIMPULAN DAN SARAN}

Berdasarkan hasil uji statistk tidak terdapat perbedaan antara jus jambu dan zigavit/multivitamin dalam mencegah penurunan kadar eritrosit setelah senam high impact.

Saran yang dapat peneliti sampaikan adalah untuk kedepannya dalam melakukan penelitian yang serupa dapat menambahkan waktu dalam memberikan perlakuan kepada responden serta menambahkan jumlah responden pada masing-masing kelompok, supaya dapat menunjukkan perbedaan yang bermakna secara statistik antara kedua kelompok.

\section{DAFTAR RUJUKAN}

Almeida, M.R.J., Mourgues, F., Rosati, C. 2004 Biochemical and molecular Charaterization of Flavanoid Pathway in Strawberry Fruits. Journal Agricultural Genetics Italy. C.(55): 419-502.

Aswin, S. 2001. Metodologi Penelitian

$$
\text { Kedokteran. FK UGM }
$$
Yogyakarta.

Cooper, K.H. 2001. Sehat Tanpa Obat : 4 Langkah Revolusi Antioksidan terjemahan dari Textbook of Antioxidant Revolution. Kaifa. Bandung hal: 233-234

Droge, W. 2002. Free Radicals in the Physiological Control of Cell Function. Physiol Rev. (82): 4795. 
Garcia, A.F., Butz, P and Tauscher, B. 2001. Effect of high-presure processing on carotenoid extractability, antioxidant activity, glucose diffusion and water binding of jambu biji merahoes puree ( Lycopenersion esculentum mill). Journal of food Science. 66 (7): 1033-1038.

Guyton, A.C. 2002. Fisiologi Manusia dan Mekanime Penyakit terjemahan dari Textbook of Human Physiology and Mekanisms of Disease $7^{\text {th }}$ ed. EGC. Jakarta.

Santoso, S. 2002. Buku Latihan SPSS Statistik Parametrik. Elex Media Komputindo, Jakarta. Hal:108109.

Sargowo, D. dan Ratnawati, R. 2002. Pengaruh Zat Aktif Ganggang Hijau Terhadap Produk Radikal Bebas dan Fraksi Lipid Penderita Dislipidemia Usia Lanjut. Medika. (11) Feb: 693-701.

Tutu, Y. 2005. Pengaruh Vitamin C Kombinasi Bioflavonoid Terhadap Jumlah pengaruh Jumlah Lekosit dan Neutrofil Pada Latihan Aerobic Tipe High Impact. Tesis. FK UGM Yogyakarta.

Vainionpaa, A., Korpelainen, R., Leppaluoto, J., Jamsa, T. 2005. Effects of high impact exercise on bone mineral density : a randomized controlled trial in premenopausal women. Journal International Osteoporosis Foundation. (16) June:191-197.

Vanket, R. Heber, D. Truscott, G,T. 2000. Lycopene jambu biji merahoes and Health. Journal of Nutrition. (1):1476-1496.
Weiss,W., Chiu, F., Schilling ,K. 2004 . Mearsurement of Resistance Exercise Force Expression. Journal Of Applied Biomechanics. 20. 204-212.

Wirakusumah, S. 2000. Jus Buah Dan Sayur Suatu Alternatif Pengganti Soft Drink. Pangan (26): 49-60.

WHO. 2004. Vitamin and Mineral Requirements in Humen Nutrition. Second Edition. Bangkok Thailand.

Wirya, I. 2002. Pemberian Suplemen Kompleks Antioksidan Pada Pelari Sprint 200 Meter Untuk Menurunkan Kadar Laktat Darah. Medika. (52) Januari: 6 - 10 